\title{
LEGAL ADJUSTMENT OF ILLEGAL EMPLOYMENT OF CHILDREN IN SLOVAK REPUBLIC
}

\author{
Peter Čonka ${ }^{1}$
}

\begin{abstract}
Illegal employment of children deserves our specific attention because the healthy development of children is one of the most important factors of an advanced society. The aim of this contribution is to provide a preview of a theme, especially in a branch of the Criminal law. The contribution deals with the definition of child labor and analyses the legal adjustment of illegal employment of children included in Criminal Code of the Slovak Republic while also pointing out international sources of this legal adjustment. The Criminal code of the Slovak Republic, the Convention on the Rights of the Child, and other relevant literature and documents about child labor are the main sources of this survey. We can consider this legal adjustment as suitable, but it is important to focus on its adherence. An important benefit of this particular analogy is a general overview on the theme of illegal child labour by analysis of relevant legal adjustment.
\end{abstract}

UDC Classification: 343.3/.7; DOI: http://dx.doi.org/10.12955/cbup.v5.986

Keywords: children, labor, employment, illegal, convention.

\section{Introduction}

Child labor is an issue that needs to be handled very carefully because incorrect procedure might cause huge damage to the children's development. Illegal employment of children might cause damage to their moral development, physical health, and it also has significant impact on truancy. Premature termination of education and truancy make it harder to find a stable job with good salary. According to the World Report on child labour (2015) some 168 million children remain trapped in child labour while at the same time there are 75 million young persons aged 15 to 24 years of age who are unemployed and many more who must settle for jobs that fail to offer a fair income, security in the workplace, social protection or other basic decent work attributes.

Child labor is typical for developing countries, but we need to focus on this issue also in Europe, because development of this unwanted phenomenon might be very dangerous. We need to take control over truancy and premature termination of education to prevent illegal child labor, because children which are not under control and which are not educated are more susceptible to be abused.

It is very positive that in the most of the European countries there is protection of children secured by Criminal law. This fact might discourage potential perpetrators and also serves as expression of the highest importance of resolving this issue.

Contribution Legal adjustment of illegal employment of children in the Slovak Republic presents legal adjustment of this issue expressed in the Criminal code with focus on international conventions as sources of this legal adjustment. The contribution also pays attention to the definition of key concepts and also focuses on connection between child labor and truancy.

\section{Illegal employment of children}

Society pays extraordinary attention to protection of children by its system of laws, and this is expressed by the fact that children are protected not only by the norms of civil law, but also by the norms of criminal law. Criminal law protects only the most important values of society so we can conclude that life, health and healthy development of children belong to the top of human interest.

Employment of children is a very specific theme which is regulated by strict rules. These rules can be found in Labour law and also in Criminal law.

The Criminal law of Slovak republic provides protection of children by the Criminal code (number 300/2005), which includes following legal adjustment in $\S 211$ :

1) Any person who, even by negligence, exposes a person under eighteen years of age to the risk of debauchery by

a) enticing such person to leading lewd or immoral life,

b) enabling such person to lead lewd or immoral life,

\footnotetext{
${ }^{1}$ Faculty of law, University of Trnava in Trnava, peter.conka13@gmail.com
} 
c) enabling such person to perform actions which are considered as criminal offenses under this Act or,

d) preventing such person from compulsory school attendance, shall be liable to a term of imprisonment of up to two years.

(2) The same sentence as referred in paragraph 1 shall be imposed on the offender, who as a contrary to a generally binding legal regulation, employs a child under fifteen years of age, and thus prevents him from compulsory school attendance.

We can conclude that the cited paragraph of the Criminal Code contains two different facts. The paragraph number one contains general protection of children to prevent the risk of their debauchery.

Objective of paragraph number two is to protect the healthy physical and mental development of children younger than fifteen years of age. This provision implements the Convention on the Rights of the Child which has been approved on 20-th of November. The Convention on the Rights of the Child describes a child as every human being below the age of eighteen years, unless under the law applicable to the child, maturity is attained earlier. State Parties shall secure life and development of children at the most possible level. According to article 19 of the Convention, state Parties shall take all appropriate legislative, administrative, social and educational measures to protect the child from all forms of physical or mental violence, injury or abuse, neglect or negligent treatment, maltreatment or exploitation, including sexual abuse, while in the care of parent(s), legal guardian(s) or any other person who has the care over the child.

According to article 27 of the Convention, state Parties recognize the right of every child to a standard of living adequate for the child's physical, mental, spiritual, moral and social development. According to article 31 of the Convention, state Parties recognize the right of the child to rest and leisure, to engage in play and recreational activities appropriate to the age of the child and to participate freely in cultural life and the arts. State Parties shall respect and promote the right of the child to participate fully in cultural and artistic life and shall encourage the provision of appropriate and equal opportunities for cultural, artistic, recreational and leisure activity. From the mentioned article, it is possible to conclude that its objective is the protection of children against illegal employment, because it guarantees the right to rest, leisure time, and versatile development.

Article 32 of the Convention explicitly protects children against illegal employment and against truancy. According to this article, state Parties recognize the right of the child to be protected from economic exploitation and from performing any work that is likely to be hazardous or to interfere with the child's education, or to be harmful to the child's health or physical, mental, spiritual, moral or social development.

State Parties shall take legislative, administrative, social and educational measures to ensure the implementation of the present article. State Parties shall in particular:

(a) establish the minimum age or minimum ages for admission to employment;

(b) determine the appropriate regulation of hours and conditions of employment;

(c) enact the appropriate penalties or other sanctions to ensure the effective enforcement with respect to the present article.

Article 36 of this Convention also refers that state Parties shall protect the child against all other forms of exploitation prejudicial to any aspects of the child's welfare.

The capability of citizens to rights and obligations in labour relations and capacity to acquire these rights and take on such obligations by one's own legal actions (labour-law capacity) comes to existence, if the Labour code do not enact different ways, by reaching 15 years of age, but the employer is not allowed to arrange a day to start work before a citizen has completed a compulsory education. The mentioned legal adjustment contributes to the protection of children against illegal employment and especially against truancy.

It is very important to protect children from early termination of education or truancy, because according to the World report on child labor (2015) it is more difficult for early school leavers to secure stable jobs, also it takes more time to do so than better-educated youth. The World report on child labor (2015) points out that these results run counter to the common perception that better- 
educated school-leavers with more specialized skill sets have relatively greater difficulty in gaining an initial foothold in the labor market.

Criminal offense - Corrupting morals of youth is committed by its subject when by contrary to the law (Labour code) employs child younger than fifteen years of age and thus prevents him from a compulsory school attendance.

The consequence of this kind of employing is that the child does not attend a school; however the law requires that the child is prevented from fulfilling this obligation. Lichá Valicová (2014) points out that when we are talking about preventing school attendance, if a person is prevented from attending a school physically or by persuading, both cases pose the potential danger and threat. The criminal offense of corrupting morals of youth is committed only if a perpetrator acts willfully. This means that a perpetrator has his own specific intent and he knows that if he will employ a child who is less than fifteen years of age, than this child can be prevented from attending a school. It is required by law that the perpetrator has knowledge about the age of the child. Criminal liability cannot arise without fulfillment of these particular elements.

It is very important to recognize the first signs of truancy by parents of truants, but sometimes even parents support their children in this behavior, because they expect money from their children's work or they think this also helps the children. Reid (2003) writes that this is a totally false and a misguided belief. Regular attendance at school matters and is critically important for a child's schooling and personal, social and academic development. As Blanco Allais and Hageman (2008) say in countries where child labor is a common phenomenon many children are excluded on a permanent basis from the education system (i.e., high levels of child labor translate into large numbers of out-of-school children). This, of course, puts a downward pressure on overall school attendance rates.

According to a survey made by the International Labour Organization on child labor and education, there is an inverse correlation between the number of working hours and the capacity of children to attend school.

Illegal employment of children is dangerous for their moral development, because this employment has no rules regulated by law and children can sometimes do work which is not suitable for them. According to United Nations' definition of child labour, it means work that is prohibited for children of certain age groups. It is work performed by children who are under the minimum age legally specified for that kind of work, or work which because of its detrimental nature or conditions, is considered unacceptable for children and is prohibited.

However according to the International Labour Office (Making progress against child labor) children worldwide are usually illegally employed in the field of agriculture, industry or household chores. It is possible to suppose that children in Europe do similar work. Muižnieks (2013) says that many of the children working across Europe have extremely hazardous occupations in agriculture, construction, small factories, or on the street. This has been reported for example in Albania, Bulgaria, Georgia, Moldova, Montenegro, Romania, Serbia, Turkey and Ukraine.

According to the International Labour Office, agriculture is by far the most prevalent sector, representing 59\% of all those of child labor and over 98 million children as a final number. Child labor in agriculture consists primarily of work on smallholder family farms, although it also extends to activities such as livestock production, fishing and aquaculture.

According to International Labour Office 54 million children around the world can be found in the services sector and 12 million in industry. These numbers are very alarming, because work in industry can be dangerous for children's organisms and it also causes truancy. The International Labour Office also declares children who are working in the services sector primarily work in hotels, restaurants, street selling, car repair shops etc.

According to a survey made by the International Labour Organization - Child labor and education: Evidence from the surveys, boys and girls often do different jobs, where girls are usually overrepresented in non-economic activities such as work in the "own household." As Blanco Allais and Hageman (2008) say they also often bear the double burden of work outside and inside the house, with little time left for schooling. 
It is possible that the situation about child labor is much better in Europe than in Africa or Asia, but for many European countries there are no available data, so it would be proper to make a survey about child labor in the states of the European Union in order to get updated statistics. Authorities should focus on prevention by greater inspection in this field to protect the correct development of children and to prevent truancy, which is related to the illegal employment of children.

\section{Conclusion}

It is possible to conclude that the protection of children needs to be secured by international conventions in order to point out the high importance of this issue by state parties.

However, inclinations of these norms to the Criminal code of the state have the greatest importance, because it makes these norms directly enforceable. Legal adjustment of this issue in the Criminal code of the Slovak Republic can be considered as an advancement to the international standards, because it implements the Convention on the Rights of the Child which has been approved on November 20. The legal frame provided by the Convention is sufficient, but we need to focus on its adherence and enforcement.

We need to gain updated statistics of illegal child labor all around the European Union to work with relevant data and to be able to adopt suitable action. It is also very important to prevent truancy, because this phenomenon helps illegal child labor to develop. Truants are often out of control and this can lead to the development of drug abuse or gambling addictions which then forces them to look for particular source of income. One of the possible ways to gain money is to make truancy more intensive and get a job. These jobs are usually not well-paid so these young truants are actually abused. We can suppose that this kind of child labor which is motivated by the need for money is present also in Europe.

\section{References}

Blanco Allais, F., Hagemann, F. (2008). Child labour and education. Evidence from SIMPOC surveys / IPEC - Geneva. Geneva: ILO, Retrieved from http://www.ucw-project.org/attachment/blanco.pdf

Criminal code (number 300/2005) Trestný zákon (číslo 300/2005) [The Slovak republic Code]. Retrieved July 10, 2017, from https://www.slov-lex.sk/pravne-predpisy/SK/ZZ/2005/300/20170101

http://www.ilo.org/ipecinfo/product/download.do?type=document\&id=26977

International Labour Office (2013). Marking progress against child labour - Global estimates and trends 2000-2012. International Labour Office, International Programme on the Elimination of Child Labour (IPEC). Geneva: International labour organization.

International labour organization (2015). World on child labor. Retrived from

Lichá Valicová, V. (2014). Trestnoprávna zodpovednost' mladistvých. Bratislava, Wolters Kluwer,s.r.o., 61 p.

Muižnieks N. (2013). Child labor in Europe: a persisting challenge. Strasbourg: Retrieved from https://www.coe.int/et/web/commissioner/-/child-labour-in-europe-a-persisting-challen-1

Reid, K. (2003). Truancy and schools, London and New York, Taylor \& Francis e - Library

The United Nations. Child labour. Retrieved from http://www.un.org/en/events/childlabourday/background.shtml 